


\title{
VILA OURO PRETO: A \\ CIDADANIA PELAS ÁGUAS, \\ ASSESSORANDO NOVAS \\ FORMAS DE AUTOGESTÃO'
}

\author{
VILA OURO PRETO: CITIZENSHIP BYTHE WATERS, \\ ASSISTING NEW FORMS OF SELF-MANAGEMENT
}

Alfio Conti² - Cristiane Locatelli - Cristiane Martins - José Mário B. Alves ${ }^{3}$ - Margarete M. A. Silva ${ }^{4}$ - Marina Beatriz Tello Olivei$\mathrm{ra}^{5}$ - Paula Lotti

\section{Resumo}

A comunidade da Vila Novo Ouro Preto, localizada na Regional Pampulha, em Belo Horizonte, é um dos exemplos de comunidade em que as ações para a melhoria do assentamento são estruturadas e realizadas com base na organização autogestionária e norteadas pelo reconhecimento das condicionantes ambientais locais. Localizada na cabeceira e ao longo do Córrego da Cidadania, com a presença de inúmeras nascentes de água limpa ao longo das vertentes ocupadas, assumiu como diretriz a recuperação ambiental local, com ênfase na gestão das águas. A mobilização da comunidade foi assessorada por organizações não governamentais locais e técnicos autônomos, em parcerias com a sociedade civil, delegando ao Poder Público o papel de agente parceiro eventual. Nesse contexto, a Vila Novo Ouro Preto se coloca na vanguarda, mostrando como os problemas podem ser minimizados e até mesmo resolvidos pelos próprios moradores, potencializando sua capacidade de atuação por meio do processo de autogestão.

Palavras-chave: Gestão das águas; Recuperação ambiental; Assentamentos informais; Córrego da Cidadania.

\begin{abstract}
The community of Vila Novo Ouro Preto, located in the region of Pampulha in Belo Horizonte, is one of the examples of community where actions to improve nesting are structured and implemented from the organization and guided self-management from the recognition of local environmental conditions. Located at the head and along the Córrego da Cidadania, with the presence of numerous springs of clear water along the slopes busy taken as a guideline to local environmental recovery, with an emphasis on water management. Community mobilization was advised by local nongovernmental organizations and technical autonomous, in partnerships with civil society autonomously, delegating to the government as an agent eventual partner. In this context, the Vila Novo Ouro Preto puts to the forefront showing how problems can be minimized or even solved by the residents themselves, enhancing its ability to work through the self-management process.
\end{abstract}

Keywords: water management, environmental recovery, informal settlements, Córrego da Cidadania. 